\title{
Thermal Treatments and Activation Procedures Used in the Preparation of Activated Carbons
}

\author{
Virginia Hernández-Montoya, Josafat García-Servin and José Iván Bueno-López \\ Instituto Tecnológico de Aguascalientes \\ México
}

\section{Introduction}

The preparation of activated carbons (ACs) generally comprises two steps, the first is the carbonization of a raw material or precursor and the second is the carbon activation. The carbonization consists of a thermal decomposition of raw materials, eliminating non-carbon species and producing a fixed carbon mass with a rudimentary pore structure (very small and closed pores are created during this step). On the other hand, the purpose of activation is to enlarge the diameters of the small pores and to create new pores and it can be carried out by chemical or physical means. During chemical activation, carbonization and activation are accomplished in a single step by carrying out thermal decomposition of the raw material impregnated with certain chemical agents such as $\mathrm{H}_{3} \mathrm{PO}_{4}, \mathrm{H}_{2} \mathrm{SO}_{4}, \mathrm{HNO}_{3}, \mathrm{NaOH}, \mathrm{KOH}$ and $\mathrm{ZnCl}_{2}$ (Hu et al., 2001; Mohamed et al., 2010). Physical or thermal activation uses an oxidizing gas $\left(\mathrm{CO}_{2}\right.$, steam, air, etc.) for the activation of carbons after carbonization, in the temperature range from 800 to $1100{ }^{\circ} \mathrm{C}$. The carbonization can be carried out using tubular furnaces, reactors, muffle furnace and, more recently, in glass reactor placed in a modified microwave oven (Foo \& Hameed, 2011; Tongpoothorn et al., 2011; Vargas et al., 2010).

Nowadays, the raw materials more used in the preparation of carbons are of lignocellulosic origin. Wood and coconut shells are the major precursors and responsible for the world production of more than 300, 000 tons/year of ACs (Mouräo et al., 2011). However, the precursor selection depends of their availability, cost and purity, but the manufacturing process and the application of the product are also important considerations (Yavuz et al., 2010). Figure 1 shows the number of publications studied in this chapter, related with the preparation of activated carbons from lignocellulosic materials in last two decades. A clear trend can be observed: the number of works increased in the years from 2000 to 2010 . The obtained carbons were mainly employed in the removal of water pollutants.

In the present chapter the principal methods used in the preparation of activated carbons from lignocellulosic materials by chemical and physical procedures are discussed. An analysis of the experimental conditions used in the synthesis of ACs has been made attending to the carbon specific surface area. Also the advantages and disadvantages of each method are discussed. 


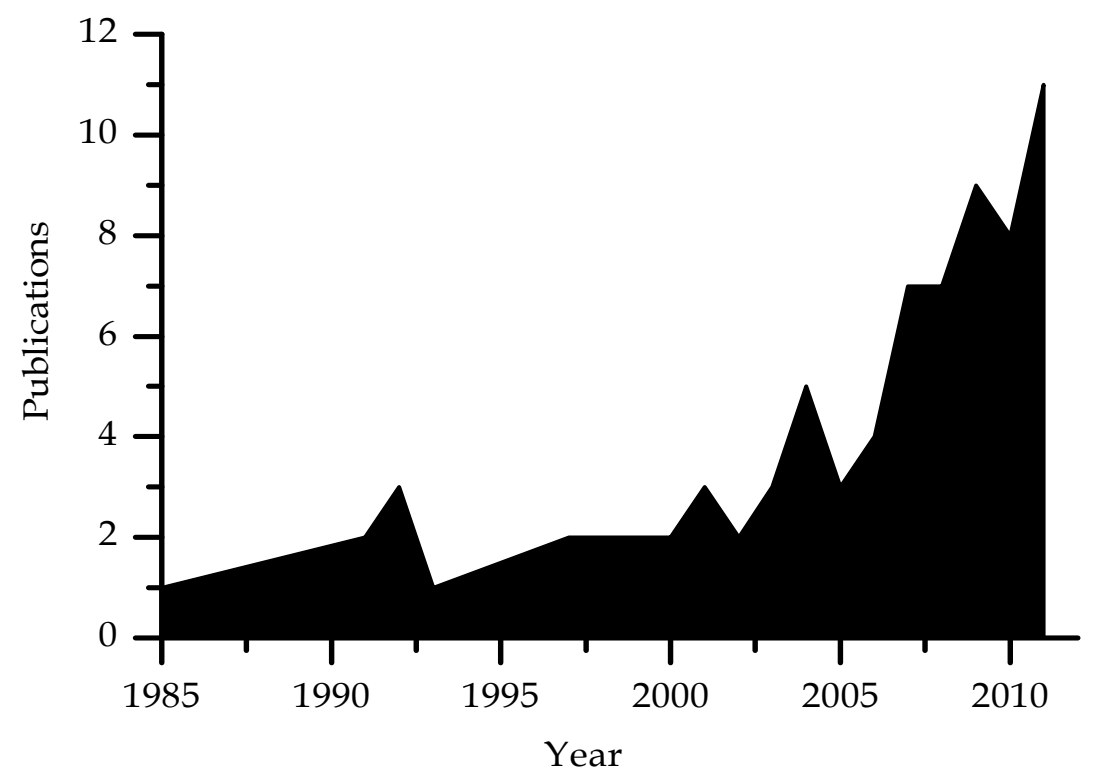

Figure 1. Number of publications related with the preparation of activated carbons from lignocellulosic precursors in the last two decades

\section{Preparation of activated carbons}

The preparation of ACs from lignocellulosic materials involved two processes, the carbonization and the activation, which can be performed in one or two steps depending on the activation method (physical or chemical, respectively). Specifically, when the carbonization is carried out in an inert atmosphere the process is called pyrolysis. According to the literature, the pyrolysis of lignocellulosic materials as coconut shells, olive stones, walnut shells, etc., gives rise to three phases: the char, oils (tars) and gases. The relative amount of each phase is a function of parameters such as temperature of pyrolysis, nitrogen flow rate and heating rate. For example, slow heating rates promote high yields of the carbon residue while flash pyrolysis is recommended for high liquid (oil) ratios (Mohamed et al., 2010).

During the pyrolysis of lignocellulosic precursors, a rudimentary porosity is obtained on the char fraction as a consequence of the release of most of the non-carbon elements such as hydrogen, oxygen and nitrogen in form of gases and tars, leaving a rigid carbon skeleton formed by aromatic structures.

There are two conventional methods for activating carbons: physical (or thermal) and chemical activation. During the chemical activation, the precursor is first impregnated or physically mixed with a chemical compound, generally a dehydrating agent. The impregnated carbon or the mixture is then heated in an inert atmosphere (Moreno-Castilla et al., 2001). On the other hand, during a physical activation process the lignocellulosic 
precursor is carbonized under an inert atmosphere, and the resulting carbon is subjected to a partial and controlled gasification at high temperature (Rodriguez-Reinoso \& MolinaSabio, 1992).

In the following sections the principal characteristics of the procedures used in the preparation of activated carbons from lignocellulosic precursors by physical and chemical methods are described.

\subsection{Chemical activation}

The carbonization step and the activation step simultaneously progress in the chemical activation (Hayashi et al., 2002a). In this case, the lignocellulosic precursor is treated primarily with a chemical agent, such as $\mathrm{H}_{3} \mathrm{PO}_{4}, \mathrm{H}_{2} \mathrm{SO}_{4}, \mathrm{HNO}_{3}, \mathrm{NaOH}, \mathrm{KOH}$ or $\mathrm{ZnCl}_{2}$ by impregnation or physical mixture and the resulting precursor is carbonized at temperatures between 400 and $800{ }^{\circ} \mathrm{C}$ under a controlled atmosphere. The function of the dehydrating agents is to inhibit the formation of tar and other undesired products during the carbonization process. Also, the pore size distribution and surface area are determined by the ratio between the mass of the chemical agent and the raw material. Besides, activation time, carbonization temperature and heating rate are important preparation variables for obtaining ACs with specific characteristics (Mohamed et al., 2010). The effects of all these parameters in the textural characteristics of ACs employing different activating agents are discussed in the following sections.

\subsubsection{Phosphoric acid $\left(\mathrm{H}_{3} \mathrm{PO}_{4}\right)$}

In the last 20 years, the activation of lignocellulosic materials with $\mathrm{H}_{3} \mathrm{PO}_{4}$ has become an increasingly used method for the large-scale manufacture of ACs because the use of this reagent has some environmental advantages such as ease of recovery, low energy cost and high carbon yield. $\mathrm{H}_{3} \mathrm{PO}_{4}$ plays two roles during the preparation of ACs: i) $\mathrm{H}_{3} \mathrm{PO}_{4}$ acts as an acid catalyst to promote bond cleavage, hydrolysis, dehydration and condensation, accompanied by cross-linking reactions between phosphoric acid and biopolymers; ii) $\mathrm{H}_{3} \mathrm{PO}_{4}$ may function as a template because the volume occupied by phosphoric acid in the interior of the activated precursor is coincident with the micropore volume of the activated carbon obtained (Zuo et al., 2009).

The chemical and physical properties of ACs obtained by chemical activation with $\mathrm{H}_{3} \mathrm{PO}_{4}$ are affected by the experimental conditions of preparation such as acid concentration, time of activation, impregnation ratio, carbonization temperature and heating rate. Also some recent works have shown that the atmosphere used in the carbonization process has an obvious effect on the physicochemical properties of ACs (Zuo et al., 2009). Table 1 collects some experimental conditions used in the preparation of activated carbons from lignocellulosic materials using $\mathrm{N}_{2}$ as activation atmosphere. 


\begin{tabular}{|c|c|c|c|c|c|}
\hline Precursor & $\begin{array}{l}\mathrm{H}_{3} \mathrm{PO}_{4} \\
(\%)\end{array}$ & $\begin{array}{l}\text { Impregnation } \\
\text { ratio }\end{array}$ & $\begin{array}{l}\text { Activation } \\
\text { temperature } \\
\left({ }^{\circ} \mathrm{C}\right)\end{array}$ & $\begin{array}{l}\text { Heating rate } \\
\left({ }^{\circ} \mathrm{C} \text { min }^{-1}\right)\end{array}$ & Reference \\
\hline $\begin{array}{l}\text { Avocado } \\
\text { kernel seed }\end{array}$ & 85 & 6 & 800 & 5 & $\begin{array}{l}\text { Elizalde- } \\
\text { González et al. } \\
\text { (2007) }\end{array}$ \\
\hline China fir & 50 & 4.6 & 475 & 5 & Zuo et al. (2009) \\
\hline $\begin{array}{l}\text { Coconut } \\
\text { Fibers }\end{array}$ & 30 & 4 & 900 & 20 & Phan et al. (2006) \\
\hline Fruit stones & 60 & 1.02 & 800 & - & Puziy et al. (2005) \\
\hline $\begin{array}{l}\text { Jackfruit peel } \\
\text { waste }\end{array}$ & 85 & 4 & 550 & - & $\begin{array}{l}\text { Prahas et al. } \\
(2008)\end{array}$ \\
\hline Jute & 30 & 4 & 900 & 20 & Phan et al. (2006) \\
\hline $\begin{array}{l}\text { Licorice } \\
\text { residues }\end{array}$ & 89 & 1.5 & 400 & 2.5 & $\begin{array}{l}\text { Kaghazchi et al. } \\
(2010)\end{array}$ \\
\hline Oil palm shell & 85 & 0.09 & 450 & 5 & $\begin{array}{l}\begin{array}{l}\text { Arami-Niya et al. } \\
(2011)\end{array} \\
\end{array}$ \\
\hline Olive Stone & 50 & 2 & 400 & 5 & \begin{tabular}{|l}
$\begin{array}{l}\text { Yavuz et al. } \\
(2010)\end{array}$ \\
\end{tabular} \\
\hline Olive waste & 75 & 2.4 & 500 & 10 & $\begin{array}{l}\text { Moreno-Castilla } \\
\text { et al. (2001) }\end{array}$ \\
\hline Pecan shell & 50 & - & 450 & - & $\begin{array}{l}\text { Ahmedna et al. } \\
(2000)\end{array}$ \\
\hline Pine Wood & 85 & 1.5 & 400 & - & $\begin{array}{l}\text { Hared et al. } \\
(2007)\end{array}$ \\
\hline $\begin{array}{l}\text { Pistachio-nut } \\
\text { shells }\end{array}$ & 89 & 0.5 & 400 & 5 & $\begin{array}{l}\text { Kaghazchi et al. } \\
(2010)\end{array}$ \\
\hline $\begin{array}{l}\text { Sea-buckthorn } \\
\text { stones }\end{array}$ & 85 & 0.5 & 550 & 10 & $\begin{array}{l}\text { Mohammadi et } \\
\text { al. (2010) }\end{array}$ \\
\hline $\begin{array}{l}\text { Stem of date } \\
\text { palm }\end{array}$ & 85 & 5 & 600 & 10 & Jibril et al. (2008) \\
\hline Tea plant & 85 & 3 & 350 & - & $\begin{array}{l}\text { Yagmur et al. } \\
(2008)\end{array}$ \\
\hline
\end{tabular}

Table 1. Experimental conditions of activated carbons obtained by chemical activation with $\mathrm{H}_{3} \mathrm{PO}_{4}$ using different lignocellulosic precursors

In most of the cited papers, the concentration of acid is greater than $50 \%(\mathrm{w} / \mathrm{w})$ and the activation temperature for $75 \%$ of these studies is between 350 and $600{ }^{\circ} \mathrm{C}$ (see Table 1). Figure 2 shows the specific surface area calculated by the Brunauer, Emmett and Teller method $\left(S_{\mathrm{BET}}\right)$ of the ACs prepared in the contributions collected in Table 1. Carbons obtained with the highest phosphoric impregnation ratio (China Fir and avocado kernel seeds) are the materials with the largest $S_{\text {BET }}\left(1785\right.$ and $\left.1802 \mathrm{~m}^{2} \mathrm{~g}^{-1}\right)$. Additionally, the carbon obtained from Oil palm shell and activated using a rather low impregnation ratio (0.09) was one of the materials with a lower specific surface area $\left(356 \mathrm{~m}^{2} \mathrm{~g}^{-1}\right)$. 


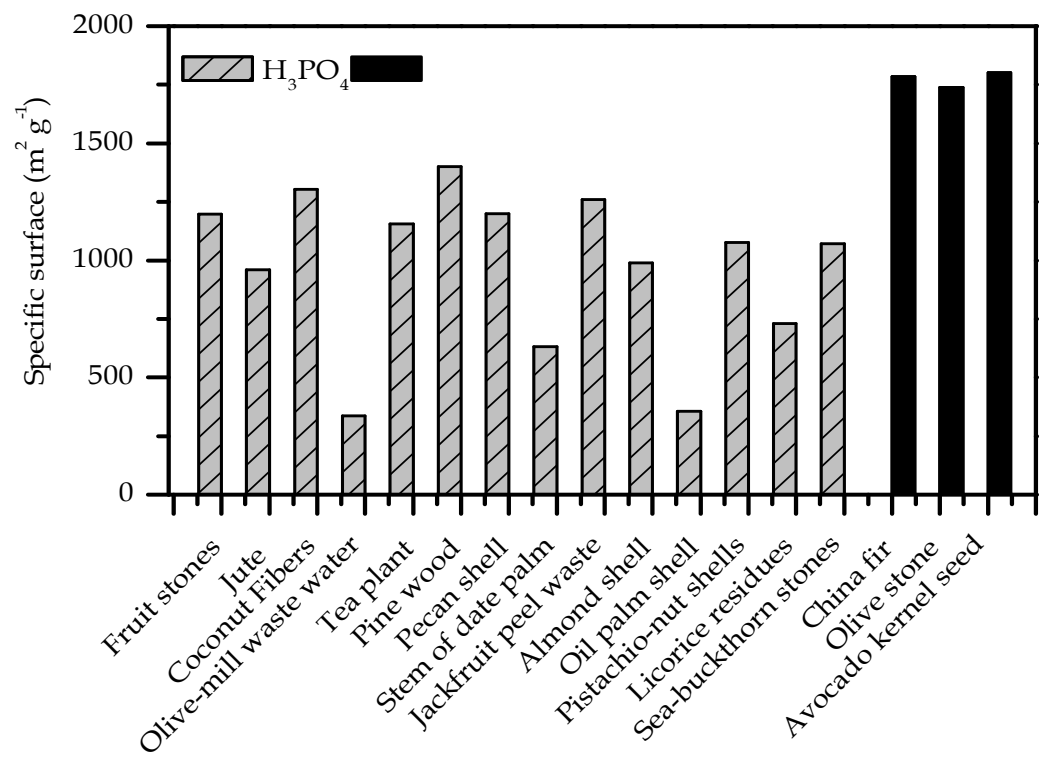

Figure 2. Specific surface area of activated carbons obtained by chemical activation of lignocellulosic materials with $\mathrm{H}_{3} \mathrm{PO}_{4}$ (black bars: ACs with greater $\mathrm{S}_{\mathrm{BET}}$ )

\subsubsection{Zinc Chloride $\left(\mathrm{ZnCl}_{2}\right)$}

Chemical activation of lignocellulosic materials with $\mathrm{ZnCl}_{2}$ leads to the production of activated carbons with good yield a well-developed porosity in only one step. Impregnation with $\mathrm{ZnCl}_{2}$ first results in degradation of the material and, on carbonization, produces dehydration that results in charring and aromatization of the carbon skeleton and creation of the pore structure (Caturla et al., 1991). In this case, the precursor is impregnated with a concentrated $\mathrm{ZnCl}_{2}$ solution during a given contact time, followed by evaporation of the solution and, finally, the precursor is carbonized in an inert atmosphere and thoroughly washed to extract the excess of $\mathrm{ZnCl}_{2}$. The amount of $\mathrm{ZnCl}_{2}$ incorporated in the precursor and the temperature of heat treatment are the two variables with a direct incidence in the development of the porosity. Table 2 shows the experimental conditions used in the preparation of $\mathrm{ACs}$ by chemical activation with $\mathrm{ZnCl}_{2}$ using $\mathrm{N}_{2}$ as activation atmosphere.

The specific surface areas of the carbons reported in the papers of Table 2 are shown in Figure 3. Carbons obtained using the highest impregnation ratios (2 and 2.5) and an activation temperature of $800{ }^{\circ} \mathrm{C}$ are the materials with the largest SET $_{\text {BET }}$ (Caturla et al., 1991; $\mathrm{Hu}$ et al., 2001). The carbon obtained from coconout shells reaches an $\mathrm{S}_{\mathrm{BET}}$ value of $2400 \mathrm{~m}^{2} \mathrm{~g}$ 1, whereas for the carbon prepared from peach stones the $S_{\text {BET }}$ was $2000 \mathrm{~m}^{2} \mathrm{~g}-1$. Other carbons prepared from coconut shells using an impregnation ratio of 1 and an activation temperature of $500{ }^{\circ} \mathrm{C}$ show lower specific surface areas $\left(1200 \mathrm{~m}^{2} \mathrm{~g}-1\right)$. In any case, all the carbons prepared by chemical activation with $\mathrm{ZnCl}_{2}$ attain $\mathrm{S}_{\text {BET }}$ greater than $750 \mathrm{~m}^{2} \mathrm{~g}^{-1}$ (Azevedo et al., 2007). The principal disadvantage of this activation is the environmental risks related to zinc compounds. 


\begin{tabular}{|c|c|c|c|c|}
\hline Precursor & $\begin{array}{l}\text { Impregnation } \\
\text { ratio (IR) }\end{array}$ & $\begin{array}{l}\text { Activation } \\
\text { temperature }\left({ }^{\circ} \mathrm{C}\right)\end{array}$ & $\begin{array}{l}\text { Heating rate } \\
\left({ }^{\circ} \mathrm{C} \mathrm{min}^{-1}\right)\end{array}$ & Reference \\
\hline $\begin{array}{l}\text { Almond } \\
\text { shells }\end{array}$ & 2 & 600 & - & $\begin{array}{l}\text { Torregrosa } \\
\text { \&Martín (1991) }\end{array}$ \\
\hline $\begin{array}{l}\text { Cherry } \\
\text { stones }\end{array}$ & 3 & 500 & 10 & $\begin{array}{l}\text { Olivares-Marín et } \\
\text { al. (2006) }\end{array}$ \\
\hline $\begin{array}{l}\text { Coconut } \\
\text { shells }\end{array}$ & 1 & 500 & 4 & $\begin{array}{l}\text { Azevedo et al. } \\
(2007)\end{array}$ \\
\hline $\begin{array}{l}\text { Coconut } \\
\text { shells* }\end{array}$ & 2 & 800 & 10 & Hu et al. (2001) \\
\hline $\begin{array}{l}\text { Coffee } \\
\text { residue }\end{array}$ & 1 & 600 & 10 & $\begin{array}{l}\text { Boudrahem et al. } \\
(2009)\end{array}$ \\
\hline Coir Pith & 1 & 700 & - & $\begin{array}{l}\text { Namasivayam \& } \\
\text { Kadirvelu (1997) }\end{array}$ \\
\hline $\begin{array}{l}\text { Hypnea } \\
\text { valentiae }\end{array}$ & - & 800 & 10 & $\begin{array}{l}\text { Aravindhan et al. } \\
(2009)\end{array}$ \\
\hline $\begin{array}{l}\text { Licorice } \\
\text { residues }\end{array}$ & 1 & 500 & 2.5 & $\begin{array}{l}\text { Kaghazchi et al. } \\
(2010)\end{array}$ \\
\hline $\begin{array}{l}\text { Oil palm } \\
\text { shell }\end{array}$ & - & 500 & 5 & $\begin{array}{l}\text { Arami-Niya et al. } \\
\text { (2011) }\end{array}$ \\
\hline $\begin{array}{l}\text { Oil palm } \\
\text { shells }\end{array}$ & - & 500 & 10 & $\begin{array}{l}\text { Arami-Niya et al. } \\
\text { (2010) }\end{array}$ \\
\hline Peach stones & 2.5 & 800 & - & $\begin{array}{l}\text { Caturla et al. } \\
\text { (1991) }\end{array}$ \\
\hline $\begin{array}{l}\text { Pistachio-nut } \\
\text { shells }\end{array}$ & 1.5 & 500 & 5 & $\begin{array}{l}\text { Kaghazchi et al. } \\
(2010)\end{array}$ \\
\hline $\begin{array}{l}\text { Sargassum } \\
\text { longifolium }\end{array}$ & - & 800 & 10 & $\begin{array}{l}\text { Aravindhan et al. } \\
\text { (2009) }\end{array}$ \\
\hline $\begin{array}{l}\text { Sea- } \\
\text { buckthorn } \\
\text { stones }\end{array}$ & 0.5 & 550 & - & $\begin{array}{l}\text { Mohammadi et al. } \\
\text { (2010) }\end{array}$ \\
\hline $\begin{array}{l}\text { Walnut } \\
\text { shells }\end{array}$ & 2 & 450 & 5 & Yang \& Qiu (2010) \\
\hline
\end{tabular}

Table 2. Experimental conditions of activated carbons obtained by chemical activation with $\mathrm{ZnCl}_{2}$ using different lignocellulosic precursors 


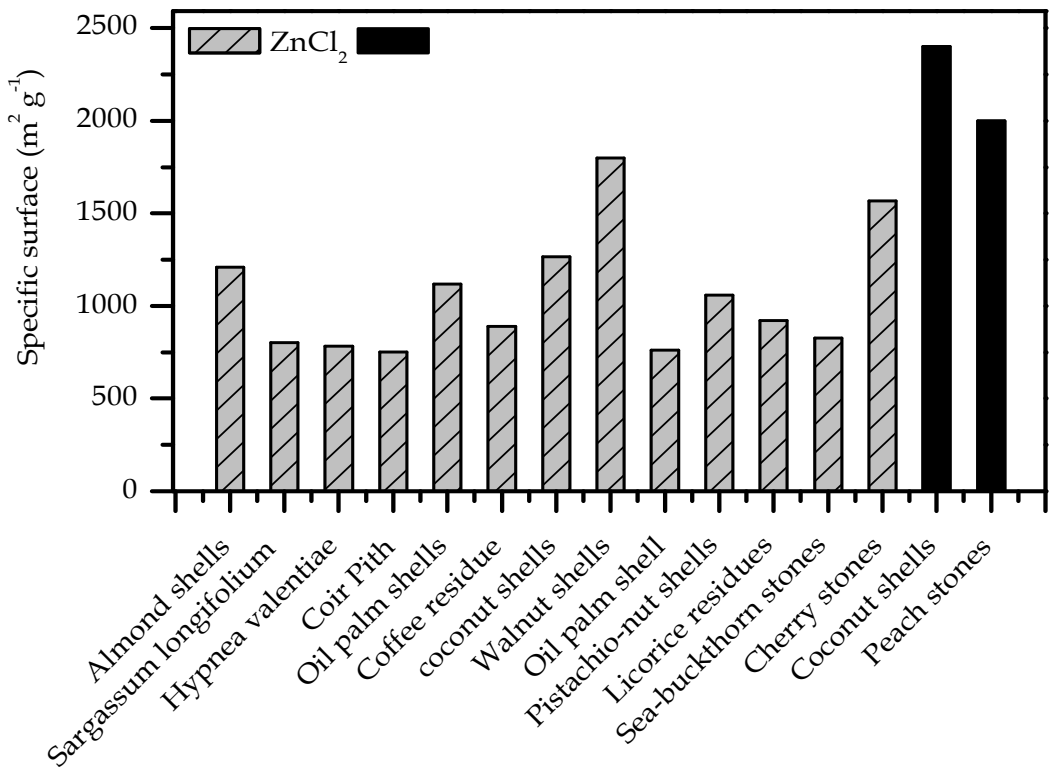

Figure 3. Specific surface area of activated carbons obtained by chemical activation of lignocellulosic materials with $\mathrm{ZnCl}_{2}$ (black bars: ACs with greater $\mathrm{S}_{\mathrm{BET}}$ )

\subsubsection{Alkalis}

Alkaline hidroxides $(\mathrm{KOH}, \mathrm{NaOH})$ and carbonates $\left(\mathrm{K}_{2} \mathrm{CO}_{3}, \mathrm{Na}_{2} \mathrm{CO}_{3}\right)$ have been used as activation reagents in the preparation of activated carbons with high specific surface. In general terms, chemical activation by $\mathrm{KOH}$ and $\mathrm{NaOH}$ consists in a solid-solid or solidliquid reaction involving the hydroxide reduction and carbon oxidation to generate porosity (Adinata et al., 2007). The activation with $\mathrm{KOH}$ was first reported in the late 1970s by AMOCO Corporation; since then many studies have been devoted to the preparation of ACs by chemical activation with $\mathrm{KOH}$ (Lua \& Yang, 2004). In this context, two procedures have been used. The carbon precursor can be mixed with powder of $\mathrm{KOH}$ or impregnated with a concentrated solution of $\mathrm{KOH}$ and then the solid mixture or impregnated precursor is thermally treated under nitrogen (Bagheri \& Abedi, 2009; Moreno-Castilla et al., 2001). Alternatively, the preparation of ACs by alkaline activation is made in two steps, in which the precursor is first pyrolyzed and the obtained carbon is activated with a solution of $\mathrm{KOH}$ (Bagheri \& Abedi, 2009) or with pellets of $\mathrm{KOH}$ and finally thermally treated again. The activation step can be conducted in a glass reactor placed in a modified micro wave oven with a frequency of $2.45 \mathrm{GHz}$ (Foo \& Hameed, 2011).

Sodium hidroxide has been also shown to be more interesting activation agent due to the possibility of reducing chemical activation costs and environmental load when compared with $\mathrm{KOH}$ activation (Tongpoothorn et al., 2011). The activation procedure with $\mathrm{NaOH}$ is similar to $\mathrm{KOH}$ (Tseng, 2007; Vargas et al., 2011). 
In general, the preparation of ACs by chemical activation with $\mathrm{KOH}$ and $\mathrm{NaOH}$ allows to obtain carbons with high specific surface areas $\left(>1000 \mathrm{~m}^{2} \mathrm{~g}^{-1}\right)$. However, $\mathrm{KOH}$ and $\mathrm{NaOH}$ are corrosive and deleterious chemicals (Hayashi et al., 2002a). For this reason, recent studies have proposed the preparation of activated carbons by chemical activation with $\mathrm{K}_{2} \mathrm{CO}_{3}$ in one step, in which the lignocellulosic materials is impregnated with a $\mathrm{K}_{2} \mathrm{CO}_{3}$ solution and finally the impregnated precursor is thermally treated. $\mathrm{K}_{2} \mathrm{CO}_{3}$ is a not deleterious reagent and it is broadly used for food additives (Hayashi et al., 2002a).

Table 3 summarizes the experimental conditions used in the preparation of ACs from lignocellulosic materials by chemical activation with $\mathrm{NaOH}, \mathrm{KOH}$ and $\mathrm{K}_{2} \mathrm{CO}_{3}$. Carbons obtained by activation with $\mathrm{NaOH}$ are the materials showing higher $\mathrm{S}_{\mathrm{BET}}$ (see Figure 4), for example, the carbon obtained from flamboyant exhibiting a $\mathrm{S}_{\mathrm{BET}}$ near to $2500 \mathrm{~m}^{2} \mathrm{~g}^{-1}$. Also, the activation with $\mathrm{K}_{2} \mathrm{CO}_{3}$ renders carbons with a competitive $S_{\mathrm{BET}}$ (between 1200 and 1800 $\mathrm{m}^{2} \mathrm{~g}^{-1}$ ) compared with those obtained by activation with $\mathrm{KOH}$ or $\mathrm{NaOH}$.

Other interesting observation is that the specific surface areas of two ACs obtained from pistachio nut shells activated with $\mathrm{KOH}$ and treated in two different thermal configurations (a conventional electric oven and a modified microwave oven), were very similar (700 and $796 \mathrm{~m}^{2} \mathrm{~g}-1$ ), thus suggesting that the two methods (conventional and non-conventional) are effective for the preparation of ACs.
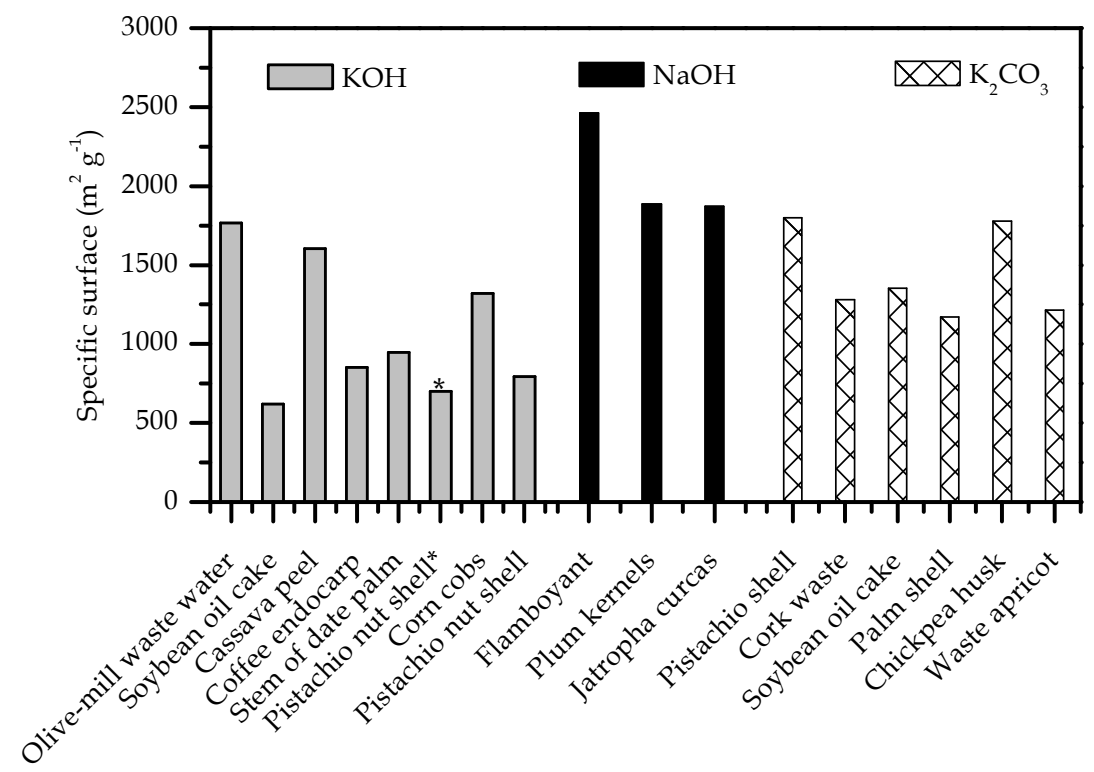

Figure 4. Specific surface area of activated carbons obtained by chemical activation of lignocellulosic materials with $\mathrm{KOH}, \mathrm{NaOH}$ and $\mathrm{K}_{2} \mathrm{CO}_{3}$ 


\begin{tabular}{|c|c|c|c|c|c|}
\hline Precursor & \begin{tabular}{|l}
$\begin{array}{l}\text { Activating } \\
\text { state }\end{array}$ \\
\end{tabular} & IR & \begin{tabular}{|l|} 
Carbonization \\
temperature $\left({ }^{\circ} \mathrm{C}\right)$
\end{tabular} & \begin{tabular}{|l}
$\begin{array}{l}\text { Heating rate } \\
\left({ }^{\circ} \mathrm{C} \text { min }^{-1}\right)\end{array}$ \\
\end{tabular} & Reference \\
\hline \multicolumn{6}{|c|}{$\mathrm{KOH}$} \\
\hline Cassava peel & - & 2.5 & 750 & 10 & $\begin{array}{l}\text { Sudaryanto et al. } \\
\text { (2006) }\end{array}$ \\
\hline $\begin{array}{l}\text { Coffee } \\
\text { endocarp }\end{array}$ & Powder & $1: 2$ & 850 & 5 & Nabais et al. (2008) \\
\hline Corn cobs & Solution & 2 & 550 & 10 & $\begin{array}{l}\text { Bagheri \& Abedi } \\
(2009)\end{array}$ \\
\hline $\begin{array}{l}\text { Olive-mill } \\
\text { waste water }\end{array}$ & Solution & 2 & 800 & 10 & $\begin{array}{l}\text { Moreno-Castilla et } \\
\text { al. (2001) }\end{array}$ \\
\hline $\begin{array}{l}\text { Pistachio nut } \\
\text { shell }\end{array}$ & Pellets & 0.5 & 300 & 10 & Lua \& Yang (2004) \\
\hline $\begin{array}{l}\text { Pistachio nut } \\
\text { shell* }^{*}\end{array}$ & Solution & 1.75 & $\begin{array}{l}\text { Frequency of } 2.45 \\
\text { GHz. }\end{array}$ & $600 \mathrm{~W}$ & \begin{tabular}{|l} 
Foo \& Hameed \\
$(2011)$
\end{tabular} \\
\hline $\begin{array}{l}\text { Soybean oil } \\
\text { cake }\end{array}$ & Solution & 0.95 & 800 & 5 & Tay et al. (2009) \\
\hline $\begin{array}{l}\text { Stem of date } \\
\text { palm }\end{array}$ & Solution & 3 & 600 & 50 & Jibril et al. (20089 \\
\hline \multicolumn{6}{|l|}{$\mathrm{NaOH}$} \\
\hline Flamboyant & Pellets & 3 & 700 & 20 & Vargas et al. (2011) \\
\hline $\begin{array}{l}\text { Jatropha } \\
\text { curcas }\end{array}$ & Solution & 4 & 400 & - & $\begin{array}{l}\text { Tongpoothorn et al. } \\
(2011)\end{array}$ \\
\hline Plum kernels & Solution & 4 & 780 & - & Tseng (2007) \\
\hline \multicolumn{6}{|l|}{$\mathrm{K}_{2} \mathrm{CO}_{3}$} \\
\hline $\begin{array}{l}\text { Chickpea } \\
\text { husk }\end{array}$ & Solution & - & 800 & 10 & $\begin{array}{l}\text { Hayashi et al. } \\
(2002 b)\end{array}$ \\
\hline Cork waste & Solution & 3 & 800 & 10 & $\begin{array}{l}\text { Carvalho et al. } \\
(2004)\end{array}$ \\
\hline Palm shell & Solution & 2 & 800 & 10 & $\begin{array}{l}\text { Adinata et al. } \\
(2007)\end{array}$ \\
\hline $\begin{array}{l}\text { Pistachio } \\
\text { shell }\end{array}$ & Solution & - & 800 & 10 & $\begin{array}{l}\text { Hayashi et al. } \\
(2002 a)\end{array}$ \\
\hline $\begin{array}{l}\text { Soybean oil } \\
\text { cake }\end{array}$ & Solution & 1 & 800 & 5 & Tay et al. (2009) \\
\hline Waste apricot & Solution & 1 & 900 & 10 & $\begin{array}{l}\text { Erdoğan et al. } \\
\text { (2005) }\end{array}$ \\
\hline
\end{tabular}

Table 3. Experimental conditions of activated carbons obtained by chemical activation with $\mathrm{NaOH}$ and $\mathrm{KOH}$ using different lignocellulosic precursors 


\subsection{Physical or thermal activation}

In a physical activation process, the lignocellulosic precursor is carbonized under an inert atmosphere, and the resulting carbon is subjected to a partial and controlled gasification at high temperature with steam, carbon dioxide, air or a mixture of these (Rodriguez-Reinoso \& Molina-Sabio, 1992). Steam and $\mathrm{CO}_{2}$ are the two activating gases more used in the physical activation of carbons. According to the literature, steam or $\mathrm{CO}_{2}$ react with the carbon structures to produce $\mathrm{CO}, \mathrm{CO}_{2}, \mathrm{H}_{2}$ or $\mathrm{CH}_{4}$. The degree of activation is normally referred to as "burn-off" and it is defined as the weight difference between the carbon and the activated carbon divided by the weight of the original carbon on dry basis according with the following equation,

$$
\text { Burn off }=\frac{W_{0}-W_{1}}{W_{0}} X 100 \%
$$

where $W_{0}$ is the weight of the original carbon and $W_{1}$ refers to the mass of the activated carbon. The use of $\mathrm{CO}_{2}$ during the activation process of a carbon material develops narrow micropores, while steam widens the initial micropores of the carbon. At high degrees of burn-off, steam generates activated carbons with larger meso and macropore volumes than those prepared by $\mathrm{CO}_{2}$. Consequently, $\mathrm{CO}_{2}$ creates activated carbons with larger micropore volumes and narrower micropore size distributions than those activated by steam (Mohamed et al., 2010)

Tables 4 and 5 show the experimental conditions used in the preparation of activated carbons from lignocellulosic materials by physical activation with $\mathrm{CO}_{2}$, steam and steam- $\mathrm{N}_{2}$ admixtures. Normally, in these experiments the lignocellulosic precursor is carbonized in an inert atmosphere $\left(\mathrm{N}_{2}\right)$ at temperatures ranging from 400 to $950{ }^{\circ} \mathrm{C}$ to produce carbons with rudimentary pore structures. These carbons are then activated with the selected gasification agent at temperatures around $800-1000{ }^{\circ} \mathrm{C}$ to produce the final activated carbons.

Some additional studies combine the thermal or physical activation with chemical activation (also known as physicochemical activation, Table 6). Normally, physicochemical activation is performed by changing the activation atmosphere of the chemical activation by a gasification atmosphere (i.e., steam) at higher temperatures. In other cases, the chemical activation is carried out directly under the presence of a gasifying agent. The combination of both types of carbon activation renders ACs with textural and chemical properties which are different from those obtained by any of the activations alone. For example, steam reduces the occurrence of heteroatoms into the carbon structures. Also, combination of oxidizing reagents in the liquid phase (i.e., nitric or sulfuric acids) with gasification agents improves the development of porosity on the final carbons.

Figure 5 shows the specific surface area of activated carbons obtained by physical and physiochemical activation according with the experimental conditions cited in Tables 4, 5 and 6. In general, the ACs obtained by physical activation with $\mathrm{CO}_{2}$ show a higher specific surface area that those obtained by activation with steam. Additionally, the ACs obtained by physical activation with $\mathrm{CO}_{2}$ using high heating rates $\left(20^{\circ} \mathrm{C} \mathrm{min}-1\right)$ are the adsorbents showing lower $\mathrm{S}_{\mathrm{BET}}$ (Corncob, Bagasse bottom ash and Sawdust fly ash). 


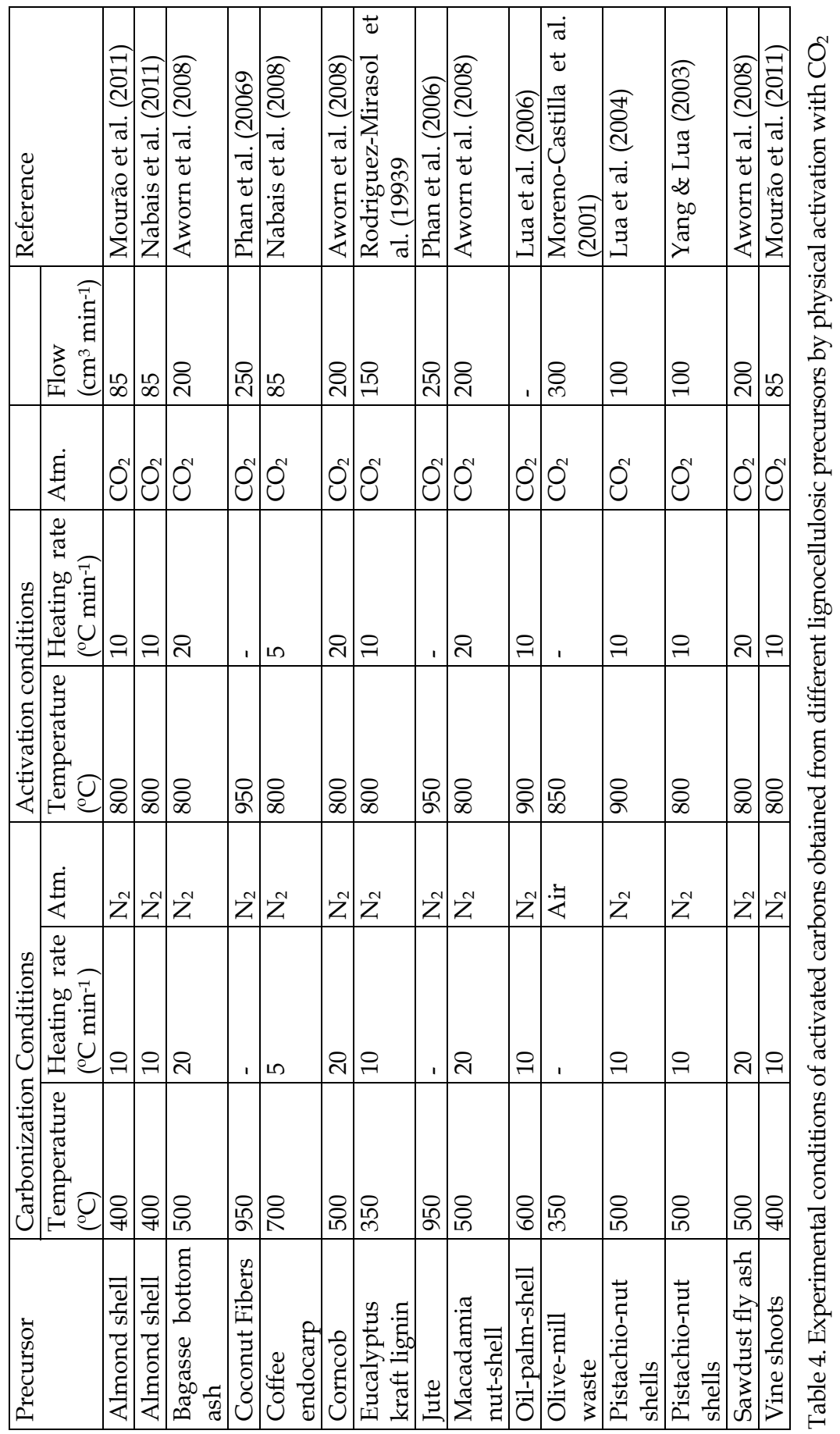




\begin{tabular}{|c|c|c|c|c|c|c|}
\hline Precursor & Carbonization & Conditions & & Activation co & ditions & \\
\hline & $\begin{array}{l}\text { Temperature } \\
\left({ }^{\circ} \mathrm{C}\right)\end{array}$ & $\begin{array}{l}\text { Heating rate } \\
\left({ }^{\circ} \mathrm{C} \text { min }^{-1}\right)\end{array}$ & Atm. & $\begin{array}{l}\text { Temperature } \\
\left({ }^{\circ} \mathrm{C}\right)\end{array}$ & $\begin{array}{l}\text { Heating rate } \\
\left({ }^{\circ} \mathrm{C} \text { min }^{-1}\right)\end{array}$ & Atm. \\
\hline Almond shell & 600 & - & $\mathrm{N}_{2}$ & 850 & - & Steam $-\mathrm{N}_{2}$ \\
\hline $\begin{array}{l}\text { Almond tree } \\
\text { pruning }\end{array}$ & 600 & - & $\mathrm{N}_{2}$ & 850 & - & Steam $-\mathrm{N}_{2}$ \\
\hline Date stones & 700 & 10 & $\mathrm{~N}_{2}$ & 700 & 10 & Steam \\
\hline $\begin{array}{l}\text { M. oleiferu } \\
\text { seed }\end{array}$ & - & - & - & 800 & 20 & Steam \\
\hline Olive stone & 600 & - & $\mathrm{N}_{2}$ & 850 & - & Steam $-\mathrm{N}_{2}$ \\
\hline Walnut shell & 600 & - & $\mathrm{N}_{2}$ & 850 & - & Steam $-\mathrm{N}_{2}$ \\
\hline
\end{tabular}

Table 5. Experimental conditions of activated carbons obtained from various lignocellulosic precursors by

\begin{tabular}{|l|l|l|l|l|l|}
\hline Precursor & $\begin{array}{l}\text { Activating } \\
\text { agent }\end{array}$ & $\begin{array}{l}\text { Temperature } \\
\left({ }^{\circ} \mathrm{C}\right)\end{array}$ & $\begin{array}{l}\text { Heating rate } \\
\left({ }^{\circ} \mathrm{C} \mathrm{min}^{-1}\right)\end{array}$ & Atm. & Flow $\left(\mathrm{cm}^{3} \mathrm{mi}\right.$ \\
\hline Date stones & $\mathrm{H}_{3} \mathrm{PO}_{4}$ & 600 & - & Steam & - \\
\hline Date stones & $\mathrm{HNO}_{3}$ & 600 & - & Steam & - \\
\hline Olive stones & $\mathrm{CaCl}_{2}$ & 800 & - & $\mathrm{CO}_{2}$ & 100 \\
\hline Sugarcane bagasse & $\mathrm{H}_{2} \mathrm{SO}_{4}$ & 160 & 10 & Air & 2000 \\
\hline
\end{tabular}

Table 6. Experimental conditions of activated carbons obtained from different lignocellulosic precurs 

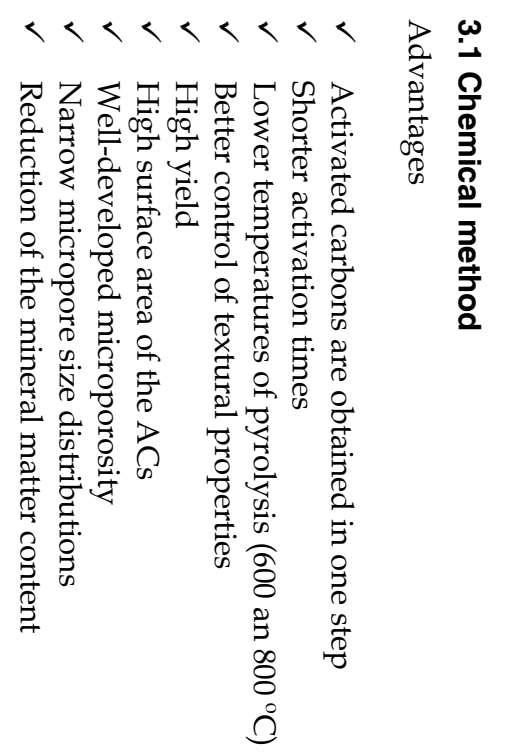

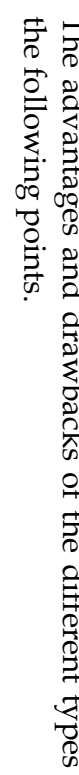

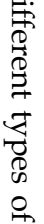

है

气

ก.

葛.

กี

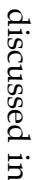

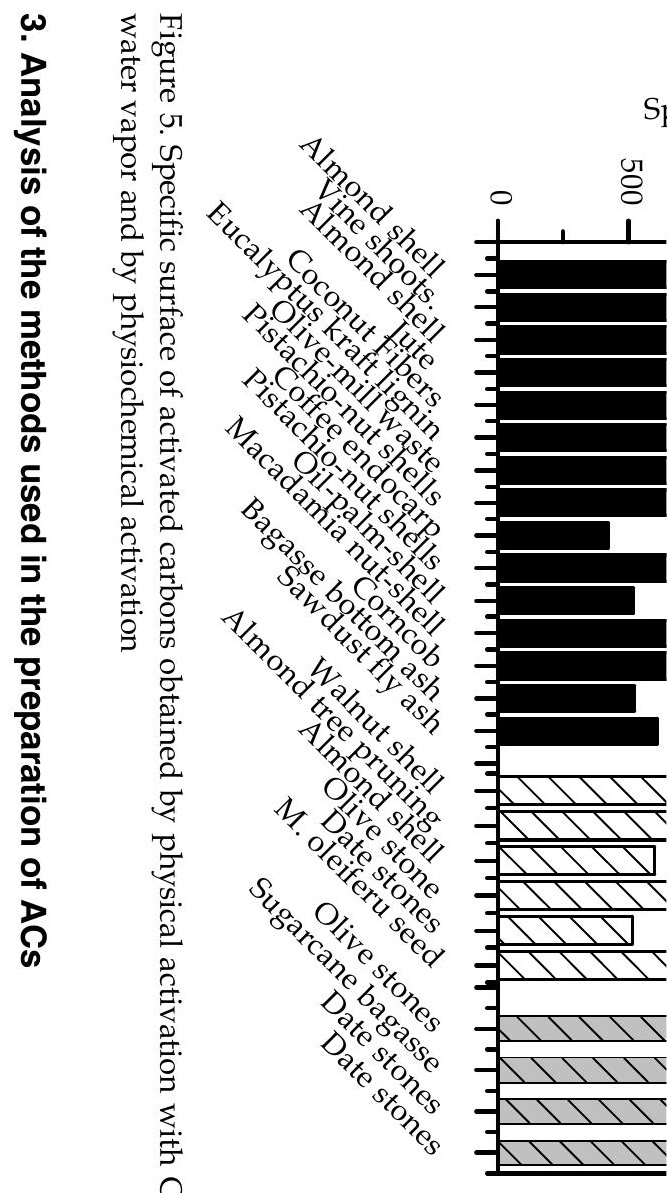


Disadvantages

$\checkmark \quad$ Corrosiveness of the process

$\checkmark$ Requires a washing stage

$\checkmark$ Inorganic impurities

$\checkmark$ More expensive

\subsection{Physical method}

Advantages

$\checkmark$ Avoids the incorporation of impurities coming from the activating agent

$\checkmark \quad$ The process is not corrosive

$\checkmark$ A washing stage is not required

$\checkmark$ Cheaper

Disadvantages

$\checkmark \quad$ The activated carbons are obtained in two steps

$\checkmark$ Higher temperatures of activation $\left(800-1000^{\circ} \mathrm{C}\right)$

$\checkmark \quad$ Poorer control of the porosity

\section{Conclusions}

Attending to the works considered in this chapter, chemical activation is the most used method for the preparation of ACs ( 60 \%) from lignocellulosic precursors. Physical activation methods is used in $28 \%$ of the studies and a low quantity of studies combine both methods (i.e., physicochemical) to produce ACs. $\mathrm{H}_{3} \mathrm{PO}_{4}$ and $\mathrm{ZnCl}_{2}$ are the two more employed activating agents in the impregnation of lignocellulosic materials (30\% and $24 \%$, respectively), whereas alkaline reagents such as $\mathrm{KOH}, \mathrm{NaOH}$ and $\mathrm{K}_{2} \mathrm{CO}_{3}$ have been considered because ACs with high specific surface can be obtained $\left(1500-2500 \mathrm{~m}^{2} \mathrm{~g}^{-1}\right)$. Physical activation of lignocellulosic precursors normally renders carbons with lower specific surface area. However, when compared with chemical activation, this method is not corrosive and does not require a washing step.

\section{Acknowledgments}

The author thanks the support of CONACYT (AGS-2010-C02-143917), DGEST (4220.11-P), Instituto Tecnológico de Aguascalientes (México) and Instituto Nacional del Carbón (Oviedo, España). 


\section{References}

[1] Adinata, D., Wan-Daud, W.M. \& Kheireddine-Aroua, M. (2007). Preparation and characterization of activated carbon from palm shell by chemical activation with $\mathrm{K}_{2} \mathrm{CO}_{3}$. Bioresource Technology, Vol. 98, No. 1, (January 2007), pp. (145-149), ISSN 0960-8524.

[2] Ahmedna, M., Marshall, W.E. \& Rao, R.M. (2000). Production of granular activated carbons from select agricultural by-products and evaluation of their physical, chemical and adsorption properties. Bioresource Technology, Vol. 71, No. 2, (January 2000), pp. (113-1239, ISSN 0960-8524. Arami-Niya, A., Daud, W.M.A.W. \& Mjalli, F.S. (2010). Using granular activated carbon prepared from oil palm shell by $\mathrm{ZnCl}_{2}$ and physical activation for methane adsorption. Journal of Analytical and Applied Pyrolysis, Vol. 89, No. 2, (November 2010), pp. (197-203), ISSN 0165-2370.

[3] Arami-Niya, A., Daud, W.M.A.W. \& Mjalli, F.S. (2011). Comparative study of the textural characteristics of oil palm shell activated carbon produced by chemical and physical activation for methane adsorption. Chemical Engineering Research and Design, Vol. 89, No. 6, (June 2011), pp. (657-664), ISSN 0263-8762.

[4] Aravindhan, R., Raghava-Rao, J. \& Unni-Nair, B. (2009). Preparation and characterization of activated carbon from marine macro-algal biomass. Journal of Hazardous Materials, Vol. 162, No. 2-3, (March 2009), pp. (688-694), ISSN 0304-3894.

[5] Aworn, A., Thiravetyan, P. \& Nakbanpote, W. (2008). Preparation and characteristics of agricultural waste activated carbon by physical activation having micro and mesopores. Journal of Analytical and Applied Pyrolysis, Vol. 82, No. 2, (July 2008), pp. (279-285), ISSN 0165-2370.

[6] Azevedo, D.C.S., Araújo, J.C.S., Bastos-Neto, M., Torres, A.E.B., Jaguaribe, E.E. \& Cavalcante C.L. (2007). Microporous activated carbon prepared from coconut shells using chemical activation with zinc chloride. Microporous and Mesoporous Materials, Vol. 100, No. 1-3, (March 2007), pp. (361-364), ISSN 1387-1811.

[7] Bagheri, N. \& Abedi, J. (2009). Preparation of high surface area activated carbon from corn by chemical activation using potassium hydroxide. Chemical Engineering Research and Design, Vol. 87, No. 8, (August 2009), pp. (1059-1064), ISSN 0263-8762.

[8] Boudrahem, F., Aissani-Benissad, F. \& Aït-Amar, H. (2009). Batch sorption dynamics and equilibrium for the removal of lead ions from aqueous phase using activated carbon developed from coffee residue activated with zinc chloride. Journal of Environmental Management, Vol. 90, No. 10, (July 2009), pp. (3031-3039), ISSN 0301-4797.

[9] Carvalho, A., Gomes, M., Mestre, A.S., Pires, J. \& Brotas de Carvalho, M. (2004). Activated carbons from cork waste by chemical activation with $\mathrm{K}_{2} \mathrm{CO}_{3}$. Application to adsorption of natural gas components. Carbon, Vol. 42, No. 3, (January 2004), pp. (667691), ISSN 0008-6223.

[10] Caturla, F., Molina-Sabio, M., \& Rodríguez-Reynoso, F. (1991). Preparation of activated carbon by Chemical activation with $\mathrm{ZnCl}_{2}$. Carbon, Vol. 29, No. 7, (February 1991), pp. (999-1007), ISSN 0008-6223.

[11] Elizalde-González, M.P., Mattusch, J., Peláez-Cid, A.A. \& Wennrich, R. (2007). Characterization of adsorbent materials preparaed from avocado kernel sedes: Natural, activated and carbonized forms. Journal of Analytical and Applied Pyrolysis, Vol. 78, No. 1, pp. (185-193), ISSN 0165-2370. 
[12] Erdoğan, S., Önal, Y., Akmil-Başar, C., Bilmez-Erdemoğlu, S., Sarıcı-Özdemir, Ç., Köseoğlu, E. \& İçduygu, G. (2005). Optimization of nickel adsorption from aqueous solution by using activated carbon prepared from waste apricot by chemical activation. Applied Surface Science, Vol. 252, No. 5, (December 2005), pp. (1324-1331), ISSN 01694332.

[13] Foo, K.Y. \& Hameed, B.H. (2011). Preparation and characterization of activated carbon from pistachio nut shells via microwave-induced chemical activation. Biomass and Energy, Vol. 35, No. 7, (July 2011), pp. (3257-3261), ISSN 0961-9534.

[14] González, J.F., Román, S., Encinar, J.M. \& Martínez, G. (2009). Pyrolysis of various biomass residues and char utilization for the production of activated carbons. Journal of Analytical and Applied Pyrolysis, Vol. 85, No. 1-2, (MAy 2009), pp. (134-141), ISSN 01652370 .

[15] Hared, I.A., Dirion, J.L., Salvador, S., Lacroix, M. \& Rio, S. (2007). Pyrolysis of wood impregnated with phosphoric acid for the production of activated carbon: Kinetics and porosity development studies. Journal of Analytical and Applied Pyrolysis, Vol. 79, No. 1-2, (May 2007), pp. (101-105), ISSN 0165-2370.

[16] Hayashi, J., Horikawa, T., Takeda, I., Muroyama, K. \& Ani, F.N. (2002a). Preparing activated carbon from various nutshells by chemical activation with $\mathrm{K}_{2} \mathrm{CO}_{3}$. Carbon, Vol. 40, No. 13, (April 2002), pp. (2381-2386), ISSN 0008-6223.

[17] Hayashi, J., Horikawa, T., Takeda, I., Muroyama, K. \& Ani, F.N. (2002b). Activated carbon from chickpea husk by chemical activation with $\mathrm{K}_{2} \mathrm{CO}_{3}$ : preparation and characterization. Microporous and Mesoporous Materials, Vol. 55, No. 1, (August 2002), pp. (63-68), ISSN 1387-1811.

[18] Hazourli S., Ziati M. \& Hazourli A. (2009). Characterization of activated carbon prepared from lignocellulosic natural residue:-Example of date stones-. Physics Procedia, Vol. 2, No. 3, (November 2009), pp. 1039-1043, ISSN 1875-3892.

[19] Hu, Z., Srinivasan, M.P. \& Ni, Y. (2001). Novel activation process for preparing highly microporous and mesoporous activated carbons. Carbon, Vol. 39, No. 6, (May 2001), pp. (877-886), ISSN 0008-6223.

[20] Jibril, B., Houache, O., Al-Maamari, R. \& Al-Rashidi, B. (2008). Effects of $\mathrm{H}_{3} \mathrm{PO}_{4}$ and $\mathrm{KOH}$ in carbonization of lignocellulosic material. Journal of Analytical and Applied Pyrolysis, Vol. 83, No. 2, (November 2008), pp. (151-156), ISSN 0165-2370.

[21] Juárez-Galán, J., Silvestre-Albero, A., Silvestre-Albero, J. \& Rodríguez-Reinoso, F. (2009). Synthesis of activated carbon with highly developed "mesoporosity". Microporous and Mesoporous Materials, Vol. 117, No. 1-2, (January 2009) pp. 519-521, ISSN 1387-1811.

[22] Kaghazchi, T., Asasian-Kolur, N. \& Soleimani, M. (2010). Licorice residue and Pistachionut shell mixture: A promising precursor for activated carbon. Journal of Industrial and Engineering Chemistry, Vol. 16, No. 3, (May 2010), pp. (368-374), ISSN 1226-086X.

[23] Lua, A.C. \& Yang, T. (2004). Effect of activation temperature on the textural and chemical properties of potassium hydroxide activated carbon prepared from pistachionut shell. Journal of Colloid and Interface Science, Vol. 274, No. 2, (June 2004), pp. (594601), ISSN 0021-9797.

[24] Lua, A.C., Lau, F.Y. \& Guo, J. (2006). Influence of pyrolysis conditions on pore development of oil-palm-shell activated carbons. Journal of Analytical and Applied Pyrolysis, Vol. 76, No. 1-2, (June 2006), pp. (96-102), ISSN 0165-2370. 
[25] Mohamed, A. R., Mohammadi, M. \& Darzi, G.N. (2010). Preparation of carbon molecular sieve from lignocellulosic biomass: A review. Renewable and Sustainable Energy Reviews, Vol. 14, No. 6, (August 2010), pp. (1591-1599), ISSN 1364-0321.

[26] Mohammadi, S.Z., Karimi, M.A., Afzali, D. \& Mansouri, F. (2010). Removal of Pb(II) from aqueous solutions using activated carbon from Sea-buckthorn stones by chemical activation. Desalination, Vol. 262, No. 1-3, (November 2010), pp. (86-93), ISSN 0011-9164.

[27] Moreno-Castilla, C., Carrasco-Marín, F., López-Ramón, M.V. \& Alvarez-Merino, M.A. (2001). Chemical and physical activation of olive-mill waste water to produce activated carbons. Carbon, Vol. 39, No. 9, (August 2001), pp. (1415-1420), ISSN 0008-6223.

[28] Mourão, P.A.M., Laginhas, C., Custódio, F., Nabais, J.M.V., Carrott, M.M.L. \& RibeiroCarrot, M.M.L. (2011). Influence of oxidation process on the adsorption capacity of activated carbons from lignocellulosic precursors. Fuel Processing Technology, Vol. 92, No. 2, (February 2011), pp. ( 241-246), ISSN 0378-3820.

[29] Nabais, J.V., Carrott, P., Ribeiro-Carrott, M.M.L., Luz, V. \& Ortiz, A.L. (2008). Influence of preparation conditions in the textural and chemical properties of activated carbons from a novel biomass precursor: The coffee endocarp. Bioresource Technology, Vol. 99, No. 15, (October 2008), pp. (7224-7231), ISSN 0960-8524.

[30] Namasivayam, C. \& Kadirvelu, K. (1997). Activated carbons prepared from coir pith by Physical and Chemical activation methods. Bioresource Technology, Vol. 62, No. 3, (December 1997), pp. (123-127), ISSN 0960-8524.

[31] Olivares-Marín, M., Fernández-González, C., Macías-García, A. \& Gómez-Serrano, V. (2006). Preparation of activated carbon from cherry stones by chemical activation with $\mathrm{ZnCl}_{2}$. Applied Surface Science, Vol. 252, No. 17, (June 2006), pp. (5967-5971), ISSN 01694332.

[32] Phan, N.H., Rio, S., Faur, C., Le Coq, L., Le Cloirec, P. \& Nguyen, T.H. (2006). Production of fibrous activated carbons from natural cellulose (jute, coconut) fibers for water treatment applications. Carbon, Vol. 44, No. 12, (October 2006), pp. (2569-2577, ISSN 0008-6223).

[33] Prahas, D., Kartika, Y., Indraswati, N. \& Ismadji, S. (2008). Activated carbon from jackfruit peel waste by $\mathrm{H}_{3} \mathrm{PO}_{4}$ chemical activation: Pore structure and surface chemistry characterization. Chemical Engineering Journal, Vol. 140, No. 1-3, (July 2008), pp. (32-42), ISSN 1385-8947.

[34] Puziy, A.M., Poddubnaya, O.I., Martínez-Alonso, A., Suárez-García, F. \& Tascón, J. (2005). Surface chemistry of phosphorus-containing carbons of lignocellulosic origin. Carbon, Vol. 43, No. 14, (November 2005), pp. (2857-2868), ISSN 0008-6223.

[35] Rodriguez-Mirasol, J., Cordero, T. \& Rodríguez, J.J. (1993). Preparation and characterization of activated Carbons from eucalyptus krafl- lignin. Carbon, Vol. 31, No. 1, (May 1992), pp. (87-95), ISSN 0008-6223.

[36] Rodríguez-Reinoso, F. \& Molina-Sabio, M. (1992). Activated carbons from lignocellulosic materials by chemical and/or physical activation: an overview. Carbon, Vol. 30, No. 7, (1992), pp. (1111-1118), ISSN 0008-6223

[37] Sudaryanto, Y., Hartono, S.B., Irawaty, W., Hindarso, H. \& Ismadji, S. (2006). High surface area activated carbon prepared from cassava peel by chemical activation. Bioresource Technology, Vol. 97, No. 5, (March 2006), pp. (734-739), ISSN 0960-8524. 
[38] Tay, T., Ucar, S. \& Karagöz, S. (2009). Preparation and characterization of activated carbon from waste biomass. Journal of Hazardous Materials, Vol. 165, No. 1-3, (June 2009), pp. (481-485), ISSN 0304-3894.

[39] Tongpoothorn, W., Sriuttha, M., Homchan, P., Chanthai, S. \& Ruangviriyachai, C. (2011). Preparation of activated carbon derived from Jatropha curcas fruit shell by simple thermo-chemical activation and characterization of their physico-chemical properties Chemical Engineering Research and Design, Vol. 89, No. 3, (March 2011), pp. (335-340), ISSN 0263-8762.

[40] Torregrosa, R. \& Martín-Martínez, J.M. (1991). Activation of lignocellulosic materials: a comparison between chemoical, physical and combined activation in terms of porous texture. Fuel, Vol. 70, No. 10, (October 1991), pp. (1173-1180), ISSN 0016-2361.

[41] Tseng, R. (2007). Physical and chemical properties and adsorption type of activated carbon prepared from plum kernels by $\mathrm{NaOH}$ activation. Journal of Hazardous Materials, Vol. 147, No. 3, (August 2007), pp. (1020-1027), ISSN 0304-3894.

[42] Valix, M., Cheung, W.H. \& McKay, G. (2004). Preparation of activated carbon using low temperature carbonisation and physical activation of high ash raw bagasse for acid dye adsorption. Chemosphere, Vol. 56, No. 5, (August 2004) pp. (493-501), ISSN 0045-6535.

[43] Vargas, J.E., Gutierrez, L.G. \& Moreno-Piraján, J.C. (2010). Preparation of activated carbons from seeds of Mucuna mutisiana by physical activation with steam. Journal of Analytical and Applied Pyrolysis, Vol. 89, No. 2, (April 2001), pp. (307-312), ISSN 01652370.

[44] Vargas, A.M.M., Cazetta, A.L., Garcia, C.A., Moraes, J.C.G., Nogami, E.M., Lenzi, E., Costa W.F. \& Almeida, V.C. (2011). Preparation and characterization of activated carbon from a new raw lignocellulosic material: Flamboyant (Delonix regia) pods. Journal of Environmental Management, Vol. 92, No. 1, (January 2011), pp. (178-184), ISSN 0301-4797.

[45] Warhurst, A.M., Fowler, G.D., McConnachie, G.L. \& Pollard, S.J.T. (1997). Pore structure and adsorption characteristics of steam pyrolysis carbons from Moringa Oleifera. Carbon, Vol. 35, No. 8, (February 1997), pp. (1039-1045), ISSN 0008-6223.

[46] Yagmur, E., Ozmak, M. \& Aktas, Z. (2008). A novel method for production of activated carbon from waste tea by chemical activation with microwave energy. Fuel, Vol. 87, No. 15-16, (November 2008), pp. (3278-3285), ISSN 0016-2361.

[47] Yang, J. \& Qiu, K. (2010). Preparation of activated carbons from walnut shells via vacuum chemical activation and their application for methylene blue removal. Chemical Engineering Journal, Vol. 165, No. 1, (November 2010), pp. (209-217), ISSN 1385-8947.

[48] Yavuz, R., Akyildiz, H., Karatepe N. \& Çetinkaya, E. (2010). Influence of preparation conditions on porous structures of olive stone activated by $\mathrm{H}_{3} \mathrm{PO}_{4}$. Fuel Processing Technology, Vol. 91, No. 1, (January 2010), pp. (80-87), ISSN 0378-3820.

[49] Zuo, S., Yang, J., Liu, J. \& Cai, X. (2009). Significance of the carbonization of volatile pyrolytic products on the properties of activated carbons from phosphoric acid activation of lignocellulosic material. Fuel Processing Technology, Vol. 90, No. 7-8, (JulyAugust 2009), pp. (994-1001), ISSN 0378-3820. 


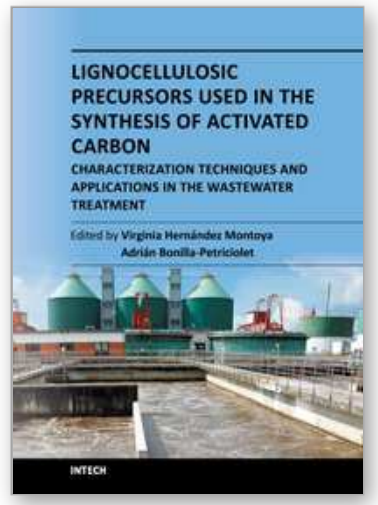

\author{
Lignocellulosic Precursors Used in the Synthesis of Activated \\ Carbon - Characterization Techniques and Applications in the \\ Wastewater Treatment \\ Edited by Dr. Virginia Hernández Montoya
}

ISBN 978-953-51-0197-0

Hard cover, 92 pages

Publisher InTech

Published online 29, February, 2012

Published in print edition February, 2012

The present book discusses the principal lignocellulosic precursors used in the elaboration of activated carbons in different countries such as Asia, America, Europe and Africa; the different methods and experimental conditions employed in the synthesis of activated carbons, including one analysis of the principal stages of the preparation such as carbonization and activation (i.e., chemical or physical activation). Also, the recent and more specialized techniques used in the characterization of activated carbons are discussed in this book. For example, the techniques employed to determine textural parameters (mercury porosimetry and gas adsorption isotherms at $77 \mathrm{~K}$ ) and different spectroscopies to determine chemical functionality (Raman, FT-IR, etc.) and other X-Ray techniques. Additionally, an overview of the application of activated carbons obtained from lignocellulosic precursors for wastewater treatment. Specifically, the analysis and discussion are focused on the advantages and capabilities of activated carbons for the removal of relevant toxic compounds and pollutants from water such as heavy metals, dyes, phenol, etc. Finally, the use of pyrolysis method for the valorization of two Mexican typical agricultural wastes (orange peel and pecan nut shell) for energy and carbon production is considered in this book.

\title{
How to reference
}

In order to correctly reference this scholarly work, feel free to copy and paste the following:

Virginia Hernández-Montoya, Josafat García-Servin and José Iván Bueno-López (2012). Thermal Treatments and Activation Procedures Used in the Preparation of Activated Carbons, Lignocellulosic Precursors Used in the Synthesis of Activated Carbon - Characterization Techniques and Applications in the Wastewater Treatment, Dr. Virginia Hernández Montoya (Ed.), ISBN: 978-953-51-0197-0, InTech, Available from: http://www.intechopen.com/books/lignocellulosic-precursors-used-in-the-synthesis-of-activated-carboncharacterization-techniques-and-applications-in-the-wastewater-treatment/no-title-specified-1

\section{INTECH}

open science | open minds

\author{
InTech Europe \\ University Campus STeP Ri \\ Slavka Krautzeka 83/A \\ 51000 Rijeka, Croatia \\ Phone: +385 (51) 770447 \\ Fax: +385 (51) 686166
}

\author{
InTech China \\ Unit 405, Office Block, Hotel Equatorial Shanghai \\ No.65, Yan An Road (West), Shanghai, 200040, China \\ 中国上海市延安西路65号上海国际贵都大饭店办公楼 405 单元 \\ Phone: +86-21-62489820 \\ Fax: +86-21-62489821
}


www.intechopen.com 
(C) 2012 The Author(s). Licensee IntechOpen. This is an open access article distributed under the terms of the Creative Commons Attribution 3.0 License, which permits unrestricted use, distribution, and reproduction in any medium, provided the original work is properly cited. 